\title{
PILKADA PASLON TUNGGAL, KINERJA PARTAI POLITIK, DAN MASA DEPAN DEMOKRASI DI INDONESIA
}

\author{
Arif Budiman \\ DKPP/Bawaslu Republik Indonesia, \\ rifandia_kafka@yahoo.co.id
}

\begin{abstract}
The number of single contestant within three occasion times of local election is continously rising. Besides, political parties are eligible to set the competition involving more than one contestant. This leads political parties performance comes into questions. Since many political scientists believed that quality of democracy depends on the degree of political parties' performance, there have been inquires on how fine Indonesian democracy will be in the future. Through qualitative approach, descriptive methods, and literature review of collecting data technique, this research concludes that the rise of single contestants has negative impact on the political parties' image and performance. Furthermore, while the quality of democracy is influenced by the political parties' performance, the decrease on their image and performance consequently leads Indonesian democracy into negative path. Political parties-backed single contestant is conclusively a threat to the future of Indonesian democracy.
\end{abstract}

Keywords: Single Contestant of Local Election, Political Parties' Performance, Democracy

\begin{abstract}
Jumlah Paslon tunggal dalam 3 (tiga) kali kesempatan Pilkada Serentak terus mengalami peningkatan. Padahal, jumlah partai politik yang memenuhi ketentuan untuk mengusung dan mendukung kandidat memungkinkan untuk terjadinya kompetisi oleh lebih dari satu pasangan calon. Kenyataan ini menimbulkan pertanyaan tentang sejauh mana kinerja partai politik di Indonesia? Selain itu, sejak banyak ilmuwan politik meyakini bahwa kualitas demokrasi dipengaruhi oleh kualitas kinerja partai politik maka pertanyaan berikut yang muncul adalah bagaimana masa depan
\end{abstract}


demokrasi di Indonesia nantinya? Melalui pendekatan kualitatif dengan metode penelitian deskriptif dan teknik pengumpulan data secara studi pustaka disimpulkan bahwa meningkatnya jumlah Paslon tunggal dalam Pilkada berpengaruh negatif terhadap citra dan kinerja partai politik. Berikutnya, oleh karena kualitas demokrasi ditentukan oleh kinerja partai politik maka penurunan citra dan kinerja partai politik juga membawa dampak negatif bagi wajah demokrasi di Indonesia. Kehadiran Paslon tunggal yang sepenuhnya didukung oleh partai politik merupakan ancaman bagi masa depan demokrasi di Indonesia.

Kata Kunci: Pilkada Paslon Tunggal, Kinerja Partai Politik, Demokrasi

\section{Pendahuluan}

\subsection{Latar belakang permasalahan}

Putusan MK Nomor 100/PUUXII/2015 tanggal 29 September 2015 memberi legitimasi bagi penyelenggaraan Pilkada dengan Paslon Tunggal. Putusan ini disambut positif oleh banyak kalangan karena dipandang dapat mengakhiri kebuntuan demokrasi, mengembalikan proses politik kepada publik, dan menyelamatkan kedaulatan rakyat untuk memilih.

Sebelumnya, beberapa Pilkada terancam tertunda karena sampai batas waktu yang ditentukan, pasangan calon yang mendaftar tidak lebih dari satu. Pada tahun 2015, ikhtiar Pasangan Calon Bupati dan Wakil Bupati Rijanto-Marhenis Urip Widodo di Blitar, Uu Ruzhanul Ulum-Ade Sugianto di Tasikmalaya, dan Raymundus Sau Fernandes-Aloysius Kobes di Timor Tengah Utara untuk menjadi Bupati dan Wakil Bupati periode kedua sempat tak jelas nasibnya karena terkendala oleh ketentuan bahwa Pilkada hanya dapat dilaksanakan jika diikuti oleh minimal dua pasangan calon.

Putusan MK a quo membawa angin segar pada ketiga wilayah tersebut, utamanya bagi pasangan calon yang telah mendaftar. Selain mengakhiri kebuntuan, putusan tersebut juga diyakini sebagai langkah tepat karena telah mengembalikan kedaulatan politik kepada publik, sekaligus membebaskan demokrasi dari sandera partai politik. Atas putusannya tersebut Mahkamah Konstitusi banyak dipuji karena telah mengembalikan hak memilih sepenuhnya kepada rakyat. Keputusan mengenai layak atau tidaknya pasangan calon untuk memimpin daerah diserahkan sepenuhnya kepada masyarakat pemilih untuk menentukan, dengan cara mencoblos kolom bergambar foto pasangan calon ataukah kolom kosong yang tidak bergambar.

Putusan MK tersebut kemudian diadopsi dalam peraturan Pilkada. Ketentuan Pasal 54C Undang-Undang Nomor 10 Tahun 2016 tentang Pemilihan Gubernur, Bupati, dan Walikota menyatakan pemilihan pasangan calon tunggal bisa dilaksanakan jika setelah penundaan dan perpanjangan masa pendaftaran tetap hanya ada satu pasangan bakal calon yang mendaftar dan memenuhi syarat.

Pasca putusan MK tersebut, kehadiran 
Paslon Tunggal dalam Pilkada semakin meningkat. Jika pada Pilkada Serentak Tahun 2015 hanya melibatkan 3 Paslon Tunggal maka pada Pilkada Serentak Tahun 2017 jumlahnya bertambah menjadi 9 Pasangan Calon, lalu angkanya membesar hampir dua kali lipat pada Pilkada Serentak Tahun 2018 dengan jumlah Paslon Tunggal mencapai 16 pasangan.

Grafik 1. Jumlah Paslon Tunggal dalam 3 Pilkada Serentak

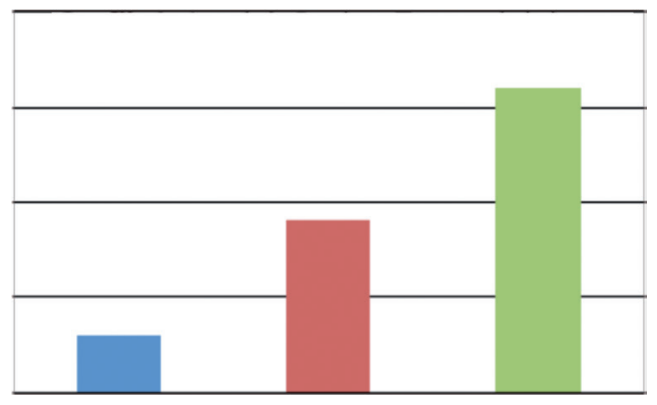

Melihat tren peningkatan Paslon Tunggal, tidak berlebihan kiranya jika muncul prediksi bahwa opsi menjadi calon tunggal dalam kontestasi Pilkada di masa-masa yang akan datang akan semakin diminati.

\subsection{Uraian permasalahan}

Kinerja partai politik menjadi salah satu indikator dari tingkat kualitas demokrasi sebuah negara. Penilaian terhadap kinerja partai politik ditentukan antara lain oleh kemampuannya dalam menjalankan fungsi pendidikan politik, sosialisasi politik, agregasi kepentingan politik, dan rekrutmen pejabat politik.

Kontestasi memperebutkan jabatan kepala daerah di Indonesia dapat menempuh satu dari dua cara yaitu melalui partai politik atau dengan menggunakan jalur perseorangan. Terdapatnya fakta di beberapa penyelenggaraan Pilkada yang dimenangkan oleh Paslon jalur perseorangan telah mengundang pertanyaan tentang sejauh mana partai politik menjalankan fungsi dan memainkan perannya dalam melakukan sosialisasi politik dan rekrutmen pejabat publik dalam sistem demokrasi elektoral di Indonesia.

Selain itu, jumlah Paslon Tunggal dalam Pilkada yang terus meningkat secara perlahan mengundang pertanyaan tentang seberapa efektif partai politik menjalankan fungsinya sebagai wadah pendidikan politik, sosialisasi politik, agregasi kepentingan politik, dan rekrutmen pejabat publik.

Penelitian mengenai fenomena Paslon Tunggal cukup banyak dilakukan. Beberapa diantaranya berupaya melakukan uji konseptual-normatif antara konsep 'pemilihan' demokratis dengan praktik Paslon Tunggal. Wafia Silvi Dhesinta (2017) menyimpulkan bahwa Pilkada Palson Tunggal tidak memenuhi prasyarat Pemilu demokratis karena meniadakan kompetisi dan kontestasi, sementara Abdul Fattah (2018) menyimpulkan bahwa Pilkda Paslon Tunggal tidak mengurangi kadar demokratis pemilihan karena sejatinya suara rakyat tidak dihambat.

Sementara itu, Firman Manan (2015) dalam penelitiannya terkait Paslon Tunggal dalam Pilkada Serentak Tahun 2015 menemukan bahwa partai politik berkontribusi besar bagi kemunculan Paslon Tunggal. Pragmatisme partai politik dengan melakukan praktik politik transaksional untuk mendapatkan insentif politik jangka pendek pasca Pilkada, konflik kepengurusan partai, dan kentalnya praktik oligarki partai 
memberi jalan bagi hadirnya pasangan calon tunggal.

Sejak partai politik diyakini menjadi variabel fundamental dalam pembangunan demokrasi politik sebuah negara, maka meningkatnya jumlah Paslon Tunggal dalam 3 (tiga) kali penyelenggaraan Pilkada di Indonesia memunculkan sejumlah pertanyaan terkait pengaruh kehadiran Paslon Tunggal dalam pembangunan demokrasi politik Indonesia di masa yang akan datang.

Penelitian ini memberikan perspektif yang berbeda dari penelitian-penelitian yang telah dilakukan mengenai Paslon Tunggal dalam Pilkada. Jika penelitian-penelitian sebelumnya banyak menguji konsep-konsep normatif dan menempatkan partai politik sebagai 'faktor penyebab' maka penelitian ini memposisikan partai politik sebagai 'pihak terdampak' yang terancam mengalami kerugian institusional oleh adanya tren Paslon Tunggal yang terus meningkat.

\subsection{Pertanyaan penelitian}

Berdasarkan uraian tersebut maka penelitian ini akan berupaya menemukan jawaban atas pertanyaan di bawah ini: "Apakah kemunculan Paslon Tunggal memperkuat kelembagaan partai politik dan mencerahkan masa depan demokrasi di Indonesia ataukah sebaliknya?"

\section{Metode Penelitian}

Penelitian ini menggunakan pendekatan kualitatif dengan metode penelitian deskriptif. Fenomena meningkatnya Paslon Tunggal dianalisa secara sistematik dengan logika induktifargumentatif berdasarkan rujukan teori yang relevan.
Data yang digunakan dalam penelitian ini diperoleh melalui studi pustaka, dengan cara membaca dan mempelajari sejumlah buku, literatur, jurnal ilmiah, website internet, dan semacamnya yang berkenaan dengan kinerja partai politik dan fenomena Paslon Tunggal. Data tersebut kemudian dianalisa dengan cara mencocokkan realitas empirik dengan teori yang berlaku dan hasilnya disajikan secara deskriptif.

\section{Perspektif Teori}

\subsection{Pasangan Calon Tunggal}

Pasangan Calon Tunggal merupakan penyebutan populer di tengah masyarakat untuk mewakili kondisi dimana Pilkada hanya diikuti oleh 1 (satu) pasangan calon. Undang-Undang Pilkada sendiri secara eksplisit menyebutnya sebagai Pemilihan 1 (satu) Pasangan Calon.

Ketentuan Pasal 54C Undang-Undang Nomor 10 Tahun 2016 menyatakan bahwa Pemilihan 1 (satu) pasangan calon dilaksanakan dalam hal memenuhi:

a. Setelah dilakukan penundaan dan sampai dengan berakhirnya masa perpanjangan pendaftaran, hanya terdapat 1 (satu) pasangan calon yang mendaftar dan berdasarkan hasil penelitian pasangan calon tersebut dinyatakan memenuhi syarat;

b. Terdapat lebih dari 1 (satu) pasangan calon yang mendaftar dan berdasarkan hasil penelitian hanya terdapat 1 (satu) pasangan calon yang dinyatakan memenuhi syarat dan setelah dilakukan penundaan sampai dengan berakhirnya masa pembukaan kembali pendaftaran tidak terdapat pasangan calon yang mendaftar atau pasangan calon 
yang mendaftar berdasarkan hasil penelitian dinyatakan tidak memenuhi syarat yang mengakibatkan hanya terdapat 1 (satu) pasangan calon;

c. Sejak penetapan pasangan calon sampai dengan saat dimulainya masa Kampanye terdapat pasangan calon yang berhalangan tetap, Partai Politik atau Gabungan Partai Politik tidak mengusulkan calon/pasangan calon pengganti atau calon/pasangan calon pengganti yang diusulkan dinyatakan tidak memenuhi syarat yang mengakibatkan hanya terdapat 1 (satu) pasangan calon;

d. Sejak dimulainya masa Kampanye sampai dengan hari pemungutan suara terdapat pasangan calon yang berhalangan tetap, Partai Politik atau Gabungan Partai Politik tidak mengusulkan calon/pasangan calon pengganti atau calon/pasangan calon pengganti yang diusulkan dinyatakan tidak memenuhi syarat yang mengakibatkan hanya terdapat 1 (satu) pasangan calon; atau

e. Terdapat pasangan calon yang dikenakan sanksi pembatalan sebagai peserta Pemilihan yang mengakibatkan hanya terdapat 1 (satu) pasangan calon.

\subsection{Kinerja Partai Politik}

Partai politik menurut Carl J. Friedrich (dalam Budiarjo, 2008) adalah sekelompok manusia yang terorganisir secara stabil dengan tujuan merebut atau mempertahankan penguasaan terhadap pemerintahan bagi pimpinan partainya, dan berdasarkan penguasaan ini, memberikan pada anggota partainya kemanfaatan yang bersifat adil serta material.
Relatif berbeda dari sudut pandang Friedrich yang memberikan penekanan pada perebutan kekuasaan untuk kemanfaatan anggota partai, Sigmund Neuman (1963) mendefinisikan partai politik dari sudut pandang kompetisi kekuasaan dan gagasan. Menurut Neuman, partai politik adalah organisasi dan aktivis-aktivis politik yang berusaha untuk menguasai kekuasaan pemerintahan serta merebut dukungan rakyat melalui persaingan dengan suatu golongan atau golongan-golongan lain yang mempunyai pandangan yang berbeda.

Dalam melakukan aktivitasnya, partai politik menjalankan berbagai fungsi, diantaranya seperti yang diuraikan Ramlan Surbakti (1992) adalah melakukan sosialisasi politik, rekrutmen politik, partisipasi politik, pemadu kepentingan, komunikasi politik, pengendalian konflik, dan kontrol politik.

Sosialisasi politik adalah proses pembentukan sikap dan orientasi politik para anggota masyarakat. Melalui proses sosialisasi politik para anggota masyarakat memperoleh sikap dan orientasi terhadap kehidupan politik yang berlangsung dalam masyarakat. Sementara itu, rekrutmen politik dimaksudkan sebagai proses seleksi dan pemilihan atau pengangkatan seseorang atau sekelompok orang untuk melaksanakan sejumlah peranan dalam sistem politik pada umumnya dan pemerintahan pada khususnya.

Dalam fungsinya sebagai sarana partisipasi politik, partai politik membuka kesempatan, mendorong dan mengajak para anggota partai politik dan anggota masyarakat yang lain untuk menggunakan partai politik sebagai saluran kegiatan mempengaruhi proses politik. Partai politik juga berfungsi menampung, 
menganalisis, dan memadukan berbagai kepentingan yang berbeda-beda, bahkan yang saling bertentangan sekalipun supaya menjadi alternatif kebijakan publik untuk selanjutnya diperjuangkan dalam proses pembuatan dan pelaksanaan keputusan politik.

Fungsi lain yang dijalankan partai politik adalah fungsi komunikasi politik, yaitu proses penyampaian informasi mengenai politik dari pemerintah kepada warga masyarakat, dan dari warga masyarakat kepada pemerintah. Tidak hanya itu, sebagai salah satu lembaga demokrasi, partai politik juga berfungsi sebagai pengendali konflik yang dilakukan dengan cara membuka dialog dengan pihak-pihak yang berkonflik, menampung dan memadukan berbagai aspirasi dan kepentingan dari pihak-pihak yang berkonflik dan membawa permasalahan kedalam musyawarah badan perwakilan rakyat (DPR) untuk mendapatkan penyelesaian berupa keputusan politik atau kompromi di antara para wakil rakyat yang berasal dari partai-partai politik.

Terakhir, partai politik juga menjalankan fungsi kontrol politik, yaitu suatu kegiatan untuk menunjukkan kesalahan, kelemahan, dan penyimpangan dalam formulasi dan implementasi kebijakan pemerintah.

Kinerja partai politik dapat diukur melalui indikator pelaksanaan fungsifungsi tersebut. Semakin baik pelaksanaan fungsi-fungsi di atas, semakin baik pula kinerja partai politik. Sebaliknya, semakin buruk fungsi-fungsi tersebut dijalankan, semakin buruk pula penilaian atas peran dan fungsi yang dilaksanakan.

Dalam konteks kemunculan Paslon Tunggal, hasil penelitian Firman Manan (2015) mendapati bahwa fungsi rekrutmen dan pelatihan yang dijalankan partai politik dalam rangka menyediakan kandidat-kandidat untuk menduduki jabatan publik tidak selalu berbanding lurus dengan proses demokratisasi. Hal tersebut bisa terjadi karena partai politik memiliki kecenderungan untuk menjadi oligarkis sebagaimana diungkap Michels dan Paul (2001) dan memiliki kebutuhan teknis yang mendesak akan kepemimpinan (Michels, 2012).

Sentralisasi pengambilan keputusan untuk menentukan kandidat oleh segelintir elite partai dan pragmatisme jangka pendek yang bersifat politis maupun ekonomis terhadap bakal calon yang akan bertanding mendorong partai politik untuk 'berbondong-bondong' mendukung kandidat yang kuat dalam hal popularitas, elektabilitas, dan logistik tanpa mempertimbangkan kepentingan kaderisasi dalam tubuh organisasi.

\subsection{Demokrasi dan Partai Politik}

Kualitas demokrasi sesungguhnya bergantung pada kualitas partai politik. Keberlangsungan fungsi-fungsi partai akan menentukan wajah demokrasi. Buruk wajah partai, buruk pula kualitas demokrasi. Sebaliknya, baik wajah partai baik pula kinerja demokrasi (Sigit Pamungkas, 2011, hlm. 62).

Pernyataan tegas Sigit Pamungkas di atas bukannya tanpa asas. Jauh sebelumnya, E.E. Schattschneider (1941) menyatakan bahwa demokrasi itu mustahil (unthinkable) tanpa partai politik. Pandangan ini diperkuat oleh studi para ilmuwan politik yang menyimpulkan bahwa partai politik memiliki perang penting dalam menentukan prestasi (Corrales, 2001), kinerja (Mainwaring dan Scully, 1995; Mainwaring, 1991), 
dan stabilitas demokrasi (Mainwaring dan Scully, 1995; Gibson 1996; dan Mc Guire, 1997) di Amerika Latin.

Huntington juga memiliki kesimpulan serupa. Berdasarkan pengamatannya terhadap proses demokratisasi negaranegara di Dunia Ketiga sejak 1974 hingga 1990-an, Huntington (1993) dengan penuh keyakinan menyatakan bahwa partai politik memiliki peran penting dalam proses konsolidasi demokrasi.

Pengakuan tentang pentingnya partai politik sebagai penentu keberhasilan konsolidasi demokrasi juga diyakini oleh Sartori (2005) berdasarkan studi sejumlah ahli politik, baik di Afrika (Clapham, 1993; Sandbrook, 1996), Asia (Diamond, 1989) atau Amerika Latin (Dix, 1992).

Konsolidasi demokrasi dimaksud menurut Giuseppe di Palma (1997) dipahami sebagai salah satu proses panjang yang membentengi kemungkinan pembalikan demokratisasi, menghindari erosi demokrasi, menghindari keruntuhan demokrasi, yang diteruskan dengan melengkapi kekurangan demokrasi, pendalaman demokrasi dan mengorganisir demokrasi secara berkelanjutan.

Dengan menggunakan pendekatan institusional, konsolidasi demokrasi menempatkan institusionalisasi politik sebagai faktor yang penting. Dalam pandangan ini, konsolidasi demokrasi harus mampu melakukan penguatan atas tiga tipe institusi politik, yaitu aparat administrasi negara (birokrasi), institusi representasi dan penyelenggaraan demokrasi (partai politik, parlemen, dan sistem pemilihan umum); dan strukturstruktur yang menjamin akuntabilitas horisontal, konstitusionalisme, dan pemerintahan berdasar hukum (sistem peradilan dan lembaga pengawasan).

Berdasarkan uraian di atas dapat disimpulkan bahwa kinerja partai politik menentukan keberhasilan konsolidasi demokrasi. Kemapanan demokrasi pada akhirnya ditentukan oleh seberapa kuat institusionalisasi politik terjadi di sepanjang jalan menuju pemapanan.

\section{Hasil dan Pembahasan}

Paslon Tunggal dalam Pilkada di Indonesia terus mengalami peningkatan. Pada penyelenggaraan Pilkada tahun 2015 yang berlangsung di 9 Provinsi, 36 Kota, dan 224 Kabupaten, muncul Paslon Tunggal sebanyak 3 (tiga) Pasangan Calon masing-masing di Kabupaten Blitar, Kabupaten Tasikmalaya, dan Kabupaten Timor Tengah Utara, sebagai berikut:

Tabel 1. Paslon Tunggal dalam Pilkada Serentak 2015

\begin{tabular}{|c|c|c|c|c|}
\hline No. & Daerah & Paslon & $\begin{array}{c}\text { Pengusung/ } \\
\text { Pendukung }\end{array}$ & Keterangan \\
\hline 1. & $\begin{array}{c}\text { Kabupaten } \\
\text { Blitar }\end{array}$ & $\begin{array}{c}\text { Rijanto-Marhenis Urip } \\
\text { Widodo }\end{array}$ & PDIP & $\begin{array}{c}\text { Petahana, } \\
\text { Koalisi Pimpinan PKB } \\
\text { boikot Pilkada }\end{array}$ \\
\hline 2. & $\begin{array}{c}\text { Kabupaten } \\
\text { Tasikmalaya }\end{array}$ & $\begin{array}{c}\text { Uu Ruzhanul Ulum-Ade } \\
\text { Sugianto }\end{array}$ & PDIP, PAN, PKS & Petahana \\
\hline 3. & $\begin{array}{c}\text { Kabupaten } \\
\text { Timor Tengah } \\
\text { Utara }\end{array}$ & $\begin{array}{c}\text { Raymundus S } \\
\text { Fernandes-Aloysius } \\
\text { Kobes }\end{array}$ & PDIP & Petahana \\
\hline
\end{tabular}

Data diolah dari berbagai sumber 
Berikutnya, pada Pilkada Serentak Tahun 2017 yang berlangsung di 7 provinsi, 76 kabupaten, dan 18 kota, jumlah Paslon Tunggal meningkat menjadi 9 Pasangan Calon, masing-masing di Kota Tebing Tinggi, Kabupaten Tulang
Bawang Barat, Kabupaten Pati, Kabupaten Landak, Kabupaten Buton, Kabupaten Maluku Tengah, Kota Jayapura, Kabupaten Tambrauw, dan Kota Sorong, dengan rincian sebagai berikut:

Tabel 2. Paslon Tunggal dalam Pilkada Serentak 2017

\begin{tabular}{|c|c|c|c|c|}
\hline No. & Daerah & Paslon & $\begin{array}{l}\text { Pengusung/ } \\
\text { Pendukung }\end{array}$ & Keterangan \\
\hline 1. & $\begin{array}{l}\text { Kota Tebing } \\
\text { Tinggi }\end{array}$ & $\begin{array}{l}\text { Umar Zunaidi Hasibuan- } \\
\text { Oki Doni Siregar }\end{array}$ & $\begin{array}{c}\text { PDIP, Golkar, Gerindra, } \\
\text { Demokrat, Nasdem, } \\
\text { PKB, Hanura, PPP }\end{array}$ & Petahana \\
\hline 2. & $\begin{array}{c}\text { Kabupaten } \\
\text { Tulang } \\
\text { Bawang Barat }\end{array}$ & $\begin{array}{c}\text { Umar Ahmad-Fauzi } \\
\text { Hasan }\end{array}$ & $\begin{array}{c}\text { PDIP, Golkar, } \\
\text { Gerindra, Demokrat, } \\
\text { Nasdem, PKB, Hanura, } \\
\text { PPP, PKS, dan PAN }\end{array}$ & Petahana \\
\hline 3. & $\begin{array}{l}\text { Kabupaten } \\
\text { Pati }\end{array}$ & Haryanto-Saiful Arifin & $\begin{array}{c}\text { PDIP, Golkar, } \\
\text { Gerindra, Demokrat, } \\
\text { PKB, Hanura, PPP, PKS }\end{array}$ & Petahana \\
\hline 4. & $\begin{array}{l}\text { Kabupaten } \\
\text { Landak }\end{array}$ & $\begin{array}{l}\text { Karolin Margret Natasa- } \\
\text { Herculanus Heriadi }\end{array}$ & $\begin{array}{c}\text { PDIP, Golkar, Gerindra, } \\
\text { Demokrat, Nasdem, } \\
\text { PKB, Hanura, PPP }\end{array}$ & Petahana \\
\hline 5. & $\begin{array}{l}\text { Kabupaten } \\
\text { Buton }\end{array}$ & $\begin{array}{l}\text { Samsu Umar Abdul } \\
\text { Samiun-La Bakry }\end{array}$ & $\begin{array}{c}\text { Golkar, Demokrat, } \\
\text { Nasdem, PKB, PKS, } \\
\text { PAN, PBB }\end{array}$ & Petahana \\
\hline 6. & $\begin{array}{c}\text { Kabupaten } \\
\text { Maluku } \\
\text { Tengah } \\
\end{array}$ & $\begin{array}{c}\text { Tuasikal Abua-Martlatu } \\
\text { Leleury }\end{array}$ & $\begin{array}{c}\text { PDIP, Golkar, Gerindra, } \\
\begin{array}{c}\text { Demokrat, Nasdem, } \\
\text { Hanura, PAN, PBB }\end{array} \\
\end{array}$ & Petahana \\
\hline 7. & Kota Jayapura & $\begin{array}{l}\text { Benhur Tomi Mano- } \\
\text { Rustan Saru }\end{array}$ & \begin{tabular}{|c|} 
PDIP, Golkar, Gerindra, \\
Nasdem, PKB, Hanura, \\
PAN
\end{tabular} & Petahana \\
\hline 8. & $\begin{array}{l}\text { Kabupaten } \\
\text { Tambrauw }\end{array}$ & $\begin{array}{l}\text { Gabriel Asem-Mesak } \\
\text { Metusala Yekwam }\end{array}$ & $\begin{array}{c}\text { PDIP, Golkar, Gerindra, } \\
\text { Demokrat, Nasdem, } \\
\text { PKB, Hanura, PKS }\end{array}$ & Petahana \\
\hline 9. & Kota Sorong & $\begin{array}{l}\text { Lamberthus Jitmau- } \\
\text { Pahima Iskandar }\end{array}$ & $\begin{array}{c}\text { PDIP, Golkar, Gerindra, } \\
\text { Demokrat, Nasdem, } \\
\text { PKB, Hanura, PAN }\end{array}$ & Petahana \\
\hline
\end{tabular}

Data diolah dari berbagai sumber

Pada penyelenggaraan Pilkada Serentak Tahun 2018 yang melibatkan 17 provinsi, 39 kota, dan 115 kabupaten, angka Paslon Tunggal bertambah hampir dua kali lipat daripada Pilkada Tahun 2017 yakni mencapai jumlah sebanyak 16 pasangan calon, masing-masing di Kabupaten Deliserdang, Kabupaten 
Padang Lawas Utara, Kota Prabumulih, Kabupaten Pasuruan, Kabupaten Lebak, Kabupaten Tangerang, Kota Tangerang, Kabupaten Tapin, Kabupaten Minahasa Tenggara, Kabupaten Bone, Kabupaten
Enrekang, Kabupaten Mamasa, Kabupaten Mamberamo Tengah, Kabupaten Puncak, Kabupaten Jayawijaya, dan Kota Makassar, dengan rincian sebagai berikut:

Tabel 3. Paslon Tunggal dalam Pilkada Serentak 2018

\begin{tabular}{|c|c|c|c|c|}
\hline No. & Daerah & Paslon & $\begin{array}{l}\text { Pengusung/ } \\
\text { Pendukung }\end{array}$ & Keterangan \\
\hline 1. & $\begin{array}{l}\text { Kabupaten } \\
\text { Deli Serdang }\end{array}$ & $\begin{array}{l}\text { Ashari Tambunan-Ali } \\
\text { Yusuf Siregar }\end{array}$ & $\begin{array}{c}\text { PDIP, Golkar, } \\
\text { Gerindra, Demokrat, } \\
\text { Nasdem, PKB, Hanura, } \\
\text { PKS, PAN, PPP, PKPI }\end{array}$ & \\
\hline 2. & $\begin{array}{c}\text { Kabupaten } \\
\text { Padang Lawas } \\
\text { Utara }\end{array}$ & $\begin{array}{l}\text { Andar Amin Harahap- } \\
\text { Hariro Harahap }\end{array}$ & \begin{tabular}{|c|} 
PDIP, Golkar, Gerindra, \\
Demokrat, Nasdem, \\
Hanura, PAN, PPP, \\
PBB, PKPI
\end{tabular} & $\begin{array}{c}\text { Walikota } \\
\text { Padangsidimpuan }\end{array}$ \\
\hline 3. & $\begin{array}{c}\text { Kota } \\
\text { Prabumulih }\end{array}$ & $\begin{array}{c}\text { Ridho Yahya- } \\
\text { Andriansyah Fikri }\end{array}$ & \begin{tabular}{|c|} 
PDIP, Golkar, Gerindra, \\
Demokrat, Nasdem, \\
Hanura, PAN, PPP, \\
PBB, PKPI
\end{tabular} & \\
\hline 4. & $\begin{array}{l}\text { Kabupaten } \\
\text { Pasuruan }\end{array}$ & $\begin{array}{l}\text { M Irsyad Yusuf-A Mujib } \\
\text { Imron }\end{array}$ & $\begin{array}{c}\text { PDIP, Golkar, } \\
\text { Gerindra, Demokrat, } \\
\text { Nasdem, PKB, Hanura, } \\
\text { PKS, PPP }\end{array}$ & Petahana \\
\hline 5. & $\begin{array}{l}\text { Kabupaten } \\
\text { Lebak }\end{array}$ & $\begin{array}{c}\text { Iti Octavia Jayabaya-Ade } \\
\text { Sumardi }\end{array}$ & $\begin{array}{c}\text { PDIP, Golkar, } \\
\text { Gerindra, Demokrat, } \\
\text { Nasdem, PKB, Hanura, } \\
\text { PKS, PAN, PPP }\end{array}$ & Petahana \\
\hline 6. & $\begin{array}{l}\text { Kabupaten } \\
\text { Tangerang }\end{array}$ & $\begin{array}{l}\text { Ahmed Zaki Iskandar- } \\
\text { Mad Romli }\end{array}$ & \begin{tabular}{|c|} 
PDIP, Golkar, Gerindra, \\
Demokrat, Nasdem, \\
PKB, Hanura, PKS, \\
PAN, PPP, PBB, PKPI
\end{tabular} & Petahana \\
\hline 7. & $\begin{array}{c}\text { Kota } \\
\text { Tangerang }\end{array}$ & $\begin{array}{c}\text { Arief R Wismansyah - } \\
\text { Sachrudin }\end{array}$ & \begin{tabular}{|c|} 
PDIP, Golkar, \\
Gerindra, Demokrat, \\
Nasdem, PKB, Hanura, \\
PKS, PPP
\end{tabular} & Petahana \\
\hline 8. & $\begin{array}{l}\text { Kabupaten } \\
\text { Tapin }\end{array}$ & $\begin{array}{c}\text { Arifin Arfan-Syariffudin } \\
\text { Noor }\end{array}$ & $\begin{array}{c}\text { PDIP, Golkar, Gerindra, } \\
\text { Demokrat, PKB, PKS, } \\
\text { PAN, PPP }\end{array}$ & Petahana \\
\hline 9. & $\begin{array}{l}\text { Kabupaten } \\
\text { Minahasa } \\
\text { Tenggara }\end{array}$ & $\begin{array}{c}\text { James Sumendap-Jesaja } \\
\text { Jocke Oscar Legi }\end{array}$ & $\begin{array}{c}\text { PDIP, Golkar, Gerindra, } \\
\text { Demokrat, Hanura, } \\
\text { PAN, PPP, PKPI }\end{array}$ & \\
\hline 10. & $\begin{array}{l}\text { Kabupaten } \\
\text { Bone }\end{array}$ & $\begin{array}{l}\text { Andi Fahsar Mahdin } \\
\text { Padjalangi-Ambo Dalle }\end{array}$ & \begin{tabular}{|c|} 
PDIP, Golkar, \\
Gerindra, Demokrat, \\
Nasdem, PKB, Hanura, \\
PKS, PAN, PPP
\end{tabular} & Petahana \\
\hline
\end{tabular}




\begin{tabular}{|c|c|c|c|c|}
\hline 11. & $\begin{array}{l}\text { Kabupaten } \\
\text { Enrekang }\end{array}$ & Muslimin Bando-Asman & $\begin{array}{c}\text { PDIP, Golkar, Gerindra, } \\
\text { Demokrat, Nasdem, } \\
\text { PAN, Hanura, }\end{array}$ & \\
\hline 12. & $\begin{array}{l}\text { Kabupaten } \\
\text { Mamasa }\end{array}$ & $\begin{array}{l}\text { Ramlan Badawi- } \\
\text { Martinus Tiranda }\end{array}$ & $\begin{array}{c}\text { PDIP, Golkar, Gerindra, } \\
\text { Demokrat, Nasdem, } \\
\text { PKB, PKS, PAN, PPP, } \\
\text { PKPI }\end{array}$ & \\
\hline 13. & $\begin{array}{c}\text { Kabupaten } \\
\text { Mamberamo } \\
\text { Tengah }\end{array}$ & $\begin{array}{l}\text { Ricky Ham Pagawak- } \\
\text { Yonas Kenelak }\end{array}$ & $\begin{array}{c}\text { PDIP, Gerindra, } \\
\text { Demokrat, PKS, PAN, } \\
\text { PBB }\end{array}$ & Petahana \\
\hline 14. & $\begin{array}{l}\text { Kabupaten } \\
\text { Puncak }\end{array}$ & $\begin{array}{l}\text { Willem Wandik-Alus } \\
\text { Murib }\end{array}$ & $\begin{array}{c}\text { PDIP, Golkar, } \\
\text { Gerindra, Demokrat, } \\
\text { Nasdem, PKB, Hanura, } \\
\text { PKS, PAN, PKPI }\end{array}$ & \\
\hline 15. & $\begin{array}{l}\text { Kabupaten } \\
\text { Jayawijaya }\end{array}$ & $\begin{array}{l}\text { Jhon Richard Banua- } \\
\text { Marthin Yogobi }\end{array}$ & $\begin{array}{c}\text { PDIP, Golkar, Gerindra, } \\
\text { Demokrat, Nasdem, } \\
\text { PKB, PKS, PAN, PKPI, } \\
\text { PBB }\end{array}$ & \\
\hline 16. & $\begin{array}{c}\text { Kota } \\
\text { Makassar }\end{array}$ & $\begin{array}{l}\text { Munafri Arifuddin-Andi } \\
\text { Rahmatika Dewi }\end{array}$ & $\begin{array}{l}\text { PDIP, Golkar, Gerindra, } \\
\text { Nasdem, Hanura, PKS, } \\
\text { PAN, PPP, PKPI, PBB }\end{array}$ & $\begin{array}{l}\text { Petahana DIAMI } \\
\text { dinyatakan TMS }\end{array}$ \\
\hline
\end{tabular}

Data diolah dari berbagai sumber

Meski jumlahnya meningkat sejak Mahkamah Konstitusi membuka peluang Paslon Tunggal, namun fenomena Paslon Tunggal ini sesungguhnya telah muncul sebelum MK memutus Perkara Nomor 100/PUU-XII/2015. Sebelum tanggal 29 September 2015, tercatat 3 Pilkada yang hanya diikuti oleh satu pasangan calon, setidaknya sampai batas akhir pendaftaran Paslon. Bedanya, jika sebelum Putusan MK a quo berlaku, kehadiran Paslon Tunggal muncul sebagai bagian dari strategi pihak lawan untuk menunda pelaksanaan Pilkada, maka setelah Putusan MK dimaksud, kehadiran Paslon Tunggal muncul sebagai pilihan strategi kandidat untuk mengunci kemenangan.

Sejak Putusan MK tersebut berlaku, aksi borong tiket partai semakin banyak. Jumlahnya bahkan berlipat. Jika pada 2017 jumlahnya mencapai 9 pasangan calon maka pada 2018 jumlahnya mencapai
16 pasangan calon. Selain itu, jika pada 2017 hanya petahana yang memborong tiket partai, maka pada 2018 tidak hanya petahana yang melakukan tindakan demikian. Fakta ini membuktikan bahwa opsi mewujudkan Paslon Tunggal dalam Pilkada merupakan strategi yang paling diminati untuk merengkuh kekuasaan melalui Pilkada.

Data di atas juga memperkuat pendapat Manan (2015), Michels dan Paul (2001), dan Michels (2012) bahwa kemunculan Paslon Tunggal dimungkinkan oleh setidaknya 2 (dua) hal, yakni adanya kecenderungan partai untuk menjadi oligarkis dan adanya kepentingan partai untuk dalam jangka pendek mendapatkan keuntungan politis dan ekonomis. Salah satu contohnya adalah Pilkada Kota Makassar Tahun 2018. Kekalahan kandidat yang didukung gabungan partai politik atas kotak kosong menunjukkan bahwa 
keputusan partai untuk mendukung kandidat lebih banyak didasarkan atas pertimbangan pragmatis para elitenya daripada kehendak mayoritas pemilih. Jika menggunakan logika kebebasan untuk memilih dan dipilih maka kehadiran Paslon Tunggal sepintas lalu terlihat demokratis. Namun, jika diteliti lebih jauh maka kemunculan Paslon Tunggal ini menyimpan banyak ironi.

Tampilnya Paslon Tunggal dalam panggung kontestasi Pilkada menunjukkan sejumlah hal, antara lain pertama, kelemahan partai politik dalam karakter ideologisnya; kedua, kegagalan partai politik dalam menjalankan fungsi kinerjanya; dan ketiga, pragmatisme partai politik dalam kebijakannya.

Bergabungnya sebagian besar atau bahkan seluruh partai politik mendukung satu pasangan calon menunjukkan ketiadaan konsistensi antara visi ideologis partai dengan sikap politik yang dipilih. Partai-partai berbasis dukungan kaum nasionalis seperti PDIP, Nasdem, Golkar, Gerindra, dan PKPI misalnya memutuskan untuk mengusung pasangan calon yang sama dengan yang diusung oleh partaipartai berbasis dukungan kaum Islamis seperti PKS, PKB, PBB, dan PPP, juga dengan pasangan calon yang diusung oleh partai-partai tengah seperti PAN dan Partai Demokrat. Hal ini terjadi hampir di seluruh wilayah (lihat Tabel 3). Alihalih menegaskan posisi ideologisnya, partai politik malah menguatkan citra pragmatisnya.

Konsistensi sikap pragmatis partai dalam penyelenggaraan Pilkada di 9 daerah pada Tahun 2017 (lihat Tabel 2) dan 16 daerah pada Tahun 2018 (lihat Tabel 3) juga mengindikasikan ketidakefektifan partai politik dalam menjalankan peran dan fungsinya. Selain gagal dalam menjalankan fungsi rekrutmen politik karena pada akhirnya mendukung pasangan calon di luar kader yang dibinanya, partai politik juga tidak mampu menjalankan fungsi sosialisasi politik. Sikap mendukung 'orang lain' menunjukkan kepercayaan diri partai politik yang lemah, hal mana bisa disebabkan oleh ketiadaan basis dukungan yang solid, luas, dan masif.

Meskipun fungsi agregasi kepentingan relatif masih bisa dijalankan, namun kemanfaatannya tak bisa diandalkan. Pada saat seluruh kekuatan politik berada di satu kutub maka sulit diharapkan dapat muncul tawaran kebijakan alternatif sebagai pembanding.

Berdasarkan uraian di atas maka dapat disimpulkan bahwa kehadiran Paslon Tunggal dalam Pilkada, utamanya yang muncul melalui modus 'borong tiket' lebih banyak melemahkan peran dan fungsi partai politik. Akibatnya, kinerja kelembagaan juga tak bisa diandalkan untuk menjadi kanal aspirasi tempat pemilih meletakkan harapan.

Fakta politik ironik sepanjang penyelenggaraan Pilkada Serentak 2017 dan 2018 sebagaimana terpampang di atas menimbulkan kekhawatiran tentang praktik demokrasi elektoral di Indonesia, perilaku pragmatik partai politik, dan wajah demokrasi politik bangsa di masa yang akan datang.

Demokrasi dianut dan didukung oleh banyak negara di dunia karena ia menjauhkan politik pemerintahan dari ancaman otoritarianisme dan oligarki kekuasaan. Pemisahan cabang kekuasaan antara eksekutif, legislatif, dan yudikatif diintroduksi demi tujuan terciptanya keseimbangan kekuasaan. Melalui 
mekanisme check and balances, setiap kebijakan membuka peluang bagi kritik dan saran perbaikan. Mekanisme ini hanya dapat berjalan dalam suatu kondisi dimana sistem politik memberikan ruang bagi partai politik untuk terlibat dalam kontestasi kekuasaan yang kompetitifsubstanstif, tidak hanya proseduralnormatif.

Faktanya, wajah partai politik di Indonesia sebelum kemunculan Paslon Tunggal sudah tidak indah. Berbagai berita negatif media terkait perilaku koruptif, migrasi keanggotaan yang menegaskan watak pragmatik, dan ketiadaan konsistensi kebijakan secara perlahan namun pasti menggerus kepercayaan masyarakat terhadap partai politik.

Berbagai penelitian telah mengonfirmasi pernyataan di atas. Mujani, Liddle, dan Ambardi (2012) dalam surveinya terkait tingkat kepercayaan masyarakat terhadap partai politik pasca Orde Baru menunjukkan adanya penurunan dalam hal tingkat kepercayaan. Pada tahun 2001 tingkat kepercayaan publik terhadap partai politik masih berada pada angka $79 \%$, namun pada tahun-tahun berikutnya angkanya terus menurun menjadi $65 \%$ pada $2002,57 \%$ pada 2005, 47\% pada 2006 dan 39\% pada 2007 dan 2008, sebagaimana grafik berikut:

\section{Grafik 2. Tingkat Kepercayaan Publik Terhadap Partai Politik}

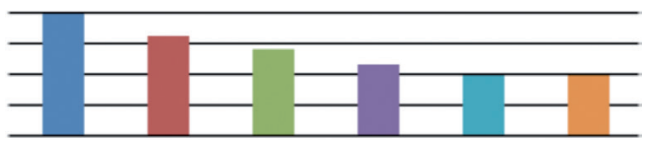

Hal yang sama ditemukan Polcomm Institute. Pada survei yang dilakukan tahun 2009, tingkat kepercayaan publik terhadap partai politik hanya tersisa sebesar $26,3 \%$, sementara yang menyatakan tidak percaya sebesar $58,2 \%$, sedangkan $15,5 \%$ lainnya menyatakan tidak tahu.

Situasi yang dihadapi partai politik di Indonesia saat ini serupa dengan yang dialami partai politik di saat Alberto Fujimori berkuasa di Peru. Levitsky dan Cameron (2001) mencatat bahwa meskipun apatisme terhadap partai politik sudah muncul sejak krisis struktural tahun 1980-an di Peru, pelemahan partai politik sampai titik terendahnya baru terjadi pada saat Presiden Fujimori berkuasa dan menerapkan sistem politik yang terpusat pada figur kandidat (candidate-centered system).

Akibat dari kebijakan tersebut, oposisi demokratis melemah. Sistem politik yang terpusat pada figur atau populisme menyebabkan para aktivis partai tidak memandang penting para pimpinan organisasi kepartaian. Loyalitas para politisi bergeser dari loyalitas vertikal menjadi loyalitas horisontal. Tidak hanya itu, akibat sistem politik yang menempatkan individu pada posisi sentral, setiap aktivis partai lebih banyak berpikir dan bertindak untuk kepentingan diri masing-masing daripada bergerak secara kelembagaan. Situasi ini membuat oposisi tidak mampu melahirkan gagasan kolektif dan kehilangan soliditas dalam melakukan gerakan.

Konsekuensi dari apatisme terhadap partai politik yang muncul akibat banyaknya fakta dan informasi negatif ini antara lain adalah munculnya pemikiran tentang menerapkan demokrasi tanpa partai politik. Gagasan ini tidak hadir tanpa dasar. Sebanyak 6 (enam) negara 
kepulauan di Pasifik yaitu Nauru, Tuvalu, Palau, Marshall Islands, Kiribati, dan Negara Federal Mikronesia menerapkan demokrasi tanpa partai politik. Meski tanpa partai politik, Freedom House memberikan skor demokrasi yang tinggi kepada enam negara ini.

Dag dan Carsten Anckar (dalam Veenendal, 2003) menjelaskan bahwa demokrasi tanpa partai politik dapat berlangsung di enam negara tersebut karena didukung oleh 3 (tiga) variabel yaitu ukuran wilayah yang kecil, kondisi geografis yang berupa kepulauan, dan resistensi kultural. Wilayah yang kecil memungkinkan warga negara saling berinteraksi secara langsung baik dengan sesama warga maupun dengan pemerintah. Sementara homogenitas budaya membuat peluang munculnya pertentangan kepentingan menjadi minimal. Kondisi ini membuat partai politik menjadi tidak terlalu dibutuhkan.

Jika Anckar melihat aspek luas wilayah, kondisi geografis, dan homogenitas budaya sebagai dasar bagi penerapan demokrasi tanpa partai politik maka Adi Prayitno (2018) melihat keberadaan negara, civil society, rakyat, dan kemajuan teknologi informasi sebagai variabel yang membuka peluang bagi penerapan demokrasi tanpa partai politik.

Dengan berpijak pada keberadaan tiga unsur penting dalam politik yakni negara, civil society, dan rakyat, Adi Prayitno mengajukan dua skenario demokrasi tanpa partai politik, yaitu pertama, jika rakyat tak lagi bisa menitipkan masa depannya kepada partai politik, maka menurutnya civil society bisa menjadi saluran alternatif untuk mengomunikasikan kepentingan rakyat dengan pemerintah. Selain itu, kepentingan rakyat juga bisa diaksentuasikan melalui anggota Dewan Perwakilan Daerah (DPD) yang notabene bebas dari partai politik.

Kedua, demokrasi cukup dibangun oleh rakyat dan pemerintah. Dengan memanfaatkan kemajuan teknologi informasi, rakyat bisa langsung menyampaikan keluh kesah dan harapannya kepada pemerintah tanpa melalui partai politik maupun civil society. Media sosial seperti Facebook, Twitter, Instagram, dan layanan media sosial lain yang tersedia 24 jam menjadi dasar bagi Prayitno untuk meyakini bahwa demokrasi bisa diterapkan tanpa harus melibatkan partai politik.

Meski belum ada uraian yang lebih praktis dan komprehensif, pemikiran Adi Prayitno ini jadi terlihat menarik di tengah naiknya apatisme masyarakat terhadap citra dan kinerja partai politik. Terlebih, kegagalan Paslon Tunggal yang didukung partai politik dalam Pilkada Kota Makassar pada Tahun 2018 memberikan satu bukti paling nyata bagaimana partai politik gagal menangkap, mengakomodasi, dan mengartikulasikan kehendak mayoritas masyarakat pemilih.

Pilkada Kota Makassar tahun 2018 memberikan pukulan telak kepada partai politik. Alih-alih memperoleh kemenangan dengan skor meyakinkan, Paslon Tunggal yang didukung seluruh partai politik yang memenuhi persyaratan malah menderita kekalahan. Peristiwa ini semakin menguatkan persepsi bahwa partai politik tidak mampu menjadi representasi aspirasi masyarakat pemilih.

\section{Simpulan}

Kehadiran Paslon Tunggal tidak menguntungkan partai politik. Jika menang maka Paslon Tunggal yang didukung 
oleh sebagian besar atau seluruh partai politik tidak bisa mewakili visi ideologis partai. Sebaliknya, kemenangannya justru menunjukkan kepada khalayak bahwa kesetiaan pada garis perjuangan partai tidak berkontribusi positif pada ikhtiar seseorang dalam perjuangannya mendapatkan kekuasaan. Dengan kata lain, tak perlu menjadi ideologis untuk mendapatkan dukungan partai politik dalam usaha memperoleh kekuasaan.

Di samping itu, kemunculan Paslon Tunggal melalui aksi borong partai dalam jangka pendek mungkin bisa mendatangkan keuntungan. Namun, fenomena tersebut membahayakan bagi daya tahan kelembagaan partai politik dalam jangka panjang. Penguasaan partai politik terhadap akses-akses sosial politik dan ekonomi mungkin saja terselamatkan, namun basis dukungan partai tak akan bisa dipertahankan. Secara perlahan, militansi akan memudar. Akibatnya, partai politik akan kehilangan elan vitalnya dalam setiap gerakan politiknya.

Kehadiran Paslon Tunggal merupakan ancaman bagi masa depan partai politik. Aksi borong partai seperti yang terjadi pada 9 daerah di Tahun 2017 dan 16 daerah di tahun 2018 menggerus peluang terjaganya mekanisme check and balances yang menjadi substansi demokrasi. Selain itu, aksi kolektif partai politik mendukung satu pasangan calon dalam Pilkada akan semakin melemahkan visi ideologis di satu sisi dan sebaliknya menguatkan karakter pragmatis partai politik di sisi yang lain. Padahal, kinerja partai politik merupakan faktor penentu bagi keberlangsungan demokrasi suatu negara.

Selain mengancam eksistensi partai politik, kemunculan Paslon Tunggal juga dapat mendegradasi substansi demokrasi Indonesia di masa yang akan datang. Untuk mencegah kondisi itu terjadi maka penguatan peran dan fungsi partai politik harus dilakukan, antara lain melalui reformasi sistem Pemilu di Indonesia dan introduksi kebijakan elektoral yang memberikan ruang dan wewenang yang lebih besar kepada partai politik khususnya dalam melakukan pendidikan, sosialisasi, dan rekrutmen politik, kecuali jika masa depan Indonesia diarahkan untuk menerapkan demokrasi tanpa partai politik.

Akhirnya, merujuk fakta sejumlah negara yang menerapkan demokrasi tanpai partai politik maka para ilmuwan politik perlu melakukan kajian lebih mendalam untuk melihat aneka alternatif yang tersedia bagi pembangunan demokrasi di masa depan. Apakah partai politik masih menempati posisi fundamental dalam bangunan demokrasi elektoral ataukah ia sekadar asesoris yang bersifat opsional. 


\section{DAFTAR PUSTAKA}

Budiardjo, Miriam. (2008). Dasar-Dasar Ilmu Politik. Jakarta: Gramedia.

Dhesinta. Wafia Silvi. (2017). Calon Tunggal dalam Pemilihan Umum Kepala Daerah dan Konsep Demokrasi: Analisa Terhadap Pemilihan Kepala Daerah Kabupaten Blitar Tahun 2015. Jurnal Jentera Volume 1 Nomor 1, Juni 2017.

Fattah, Abdul. (2018). Pemilihan Kepala Daerah dengan Calon Tunggal dalam Perspektif Shura. Hasil Penelitian dapat dilihat melalui laman http://digilib.uinsby. ac.id/26009/1/Abdul\%20Fattah_F12214115.pdf

Giuseppe di Palma. (1997). Kiat Membangun Demokrasi: Sebuah Esai Tentang Transisi Demokrasi. Jakarta: Yayasan Sumber Agung

Levitsky, S., \& Cameron, M.A. Democracy Without Parties? Political Parties and Regime Change in Fujimori's Peru. Makalah disampaikan pada Congress of the Latin American Studies Association di Washington DC, 6-8 September, 2001.

Manan, Firman, Pemilihan Kepala Daerah Dengan Pasangan Calon Tunggal Dalam Pilkada Serentak 2015. Hasil Penelitian disampaikan pada Seminar Nasional Menyongsong Pemilihan Kepala Daerah Serentak Tahun 2015, Universitas Hasanuddin, Makassar, 10 November 2015

Mujani, S., Liddle, R. W., \& Ambardi, K. (2012). KUASA RAKYAT Analisis tentang Perilaku Memilih dalam Pemilihan Legislatif dan Presiden Indonesia PascaOrdeBaru. Jakarta: Mizan

Neuman, S. (1963). Modern Political Parties, dalam Comparative Politics: A Reader, diedit oleh Harry Ecktein dan David E. Apter. London: The Free Press of Glencoe.

Pamungkas, S. (2011). Partai Politik Teori Dan Praktik di Indonesia. Yogyakarta: Institute For Democracy And Welfarism (IDW).

Prayitno, Adi. (2017, Mei 2018). Demokrasi Tanpa Partai Politik. Koran Sindo, diakses dari https://nasional.sindonews.com/read/1206041/18/demokrasitanpa-partai-politik-1495071040/13

Sartori, G. (2005). Parties and Party Systems. Colchester: ECPR

Surbakti, R. (1992). Memahami Ilmu Politik. Jakarta: Gramedia Widiasarana Indonesia

Veenendal, W. P. (2013). How Democracy Functions Without Parties: The Republic of Palau. Sage Publications. Artikel bisa diakses melalui http://ppq.sagepub. com/content/early/2013/ 11/20/1354068813509524 
134 | Jurnal Adhyasta Pemilu 